\title{
CHEMICAL ATTRIBUTES OF A DEGRADED SOIL AFTER APPLICATION OF WATER TREATMENT SLUDGES
}

\author{
Érica Tomé da Silva ${ }^{1}$; Wanderley José de Melo ${ }^{2 *}$; Sandra Tereza Teixeira ${ }^{1}$ \\ ${ }^{l} U N E S P / F C A V$ - Programa de Pós-Graduação em Produção Vegetal. \\ ${ }^{2}$ UNESP/FCAV - Depto. de Tecnologia, Via de Acesso Prof.Paulo Donato Castellane, km 5 - 14884-900 - Jaboticabal, \\ SP - Brasil. \\ *Corresponding author <wjmelo@fcav.unesp.br>
}

\begin{abstract}
Mining is an activity that tends to degrade the environment. The restoration of mining areas, aims to accelerate and improve the succession process according to its future use. The objective of this work was to rehabilitate a soil degraded by tin mining activities in the Amazon Basin (Jamari National Forest, State of Rondônia) with the application of water treatment sludge (WTS), and verify the effect of sludge on values of $\mathrm{pH}\left(\mathrm{CaCl}_{2} 0.01 \mathrm{~mol} \mathrm{~L}^{-1}\right)$, organic matter, $\mathrm{P}, \mathrm{Ca}, \mathrm{Mg}, \mathrm{K}, \mathrm{H}+\mathrm{Al}$, and soil micronutrient contents when cultivated with native plants, legumes, and grass species. A factorial $(3 \times 5)$ experimental design was used to optimize the rehabilitation of these areas including three $\mathrm{N}$ rates $(100,200$, and $300 \mathrm{mg}$ $\mathrm{N} \mathrm{kg}^{-1}$ soil supplied by WTS), five plant species (grasses, legumes, and native plants), and two controls (degraded soil with no fertilizer and degraded soil fertilized with mineral fertilizers), with four replications. WTS increased $\mathrm{pH}$ values. The chemical products used to treat the water contributed, in greater extension, to increase soil $\mathrm{Ca}$ and Fe contents. The use of WTS as fertilizer proved viable, since it contains nutrients for plants; however, nitrogen should not be used as a criterion to define the rate of sludge application, because it is present at small amounts in the WTS.
\end{abstract}

Key words: soil fertility, micronutrient, tin mining, soil reclaiming, residue

\section{ATRIBUTOS QUÍMICOS EM SOLO DEGRADADO APÓS APLICAÇÃO DE LODO DE ESTAÇÃO DE TRATAMENTO DE ÁGUA}

\begin{abstract}
RESUMO: A mineração é uma atividade que tende a degradar o ambiente. A recuperação destas áreas visa acelerar o processo de sucessão e, se possível, melhorá-las de acordo com o uso futuro. O objetivo deste trabalho foi avaliar o efeito da aplicação de lodo de Estação de Tratamento de Água (ETA) em solo degradado pela mineração de cassiterita na Floresta Nacional do Jamari, RO, sobre atributos de fertilidade do solo e sobre o conteúdo em micronutrientes, quando cultivado com plantas pioneiras, leguminosas e gramíneas. $\mathrm{O}$ delineamento experimental foi inteiramente casualizado em esquema fatorial $3 \times 5$ com 4 repetições. Os tratamentos incluíram três doses de nitrogênio (100, 200 e $300 \mathrm{mg} \mathrm{de} \mathrm{N} \mathrm{kg}^{-1}$ solo), fornecidas pelo lodo de ETA, cinco tipos de plantas (gramínea, leguminosa e pioneira) e duas testemunhas (solo degradado sem e com fertilização mineral). O lodo de ETA aumentou o pH do solo degradado. Os produtos utilizados no tratamento químico da água contribuíram para aumentar, em maior proporção, os teores de $\mathrm{Ca}$ e Fe no solo. O uso do lodo de ETA como fertilizante mostrou-se viável, porque contém nutrientes de plantas, no entanto o nitrogênio não deve ser utilizado como critério para definir as doses de aplicação, porque este se encontra em pequena quantidade no lodo de ETA.

Palavras-chave: fertilidade do solo, micronutrientes, mineração de estanho, recuperação, resíduos
\end{abstract}

\section{INTRODUCTION}

Mining is an important activity for regional development. However, because of its extractivist nature, it tends to degrade the environment. The most important loss is observed in the soil's fertile layer, where organic matter, soil fauna, and nutrients are concentrated (Griffith et al., 1990).

The recovery of degraded areas by men, aims to accelerate the succession process and, if possible, improve such areas in accordance with their future use. Grasses and legumes have been suggested among the species used to begin revegetation (Barth, 1986). Among grasses, Brachiaria decumbens has been the most popular because of its ruggedness (Fonseca, 1987; Rocha, 1986). Legumes, such as velvet bean, sunn hemp, and lablab offer great soil protection, respond favorably to the application of fertilizers, and fix atmospheric N. As a mineral fertilizer, $\mathrm{N}$ has been an essential element for the development of grasses, including $B$. decumbens, when grown in degraded areas (Silva et al., 1995, Coppin \& Bradshaw, 1982). $\mathrm{P}$ and $\mathrm{K}$ have also played important roles. 
Water Treatment Sludge (WTS) is an inorganic residue, containing on average $3 \% \mathrm{C}$ and $0.6 \%$ organic$\mathrm{N}$ (Elliott et al., 1990), so that it could replace, at least in part, the mineral fertilization used in the recovery of degraded areas. This use would help solve another huge environmental problem, the destination of WTS, since the estimated production of this residue in the São Paulo Metropolitan region is about 2,200 L s' at present all of it is returned to water streams

The objective of this work was to evaluate the effects of WTS doses applied to a soil degraded by tin mining, and cultivated with a pioneer species associated to grasses and legumes, on soil chemical attributes.

\section{MATERIAL AND METHODS}

A sample of Typic Hapludox, collected on the surface layer $(0-20 \mathrm{~cm})$ of an area degraded by tin mining at Floresta Nacional do Jamari (Jamary National Forest) $\left(09^{\circ} 15^{\prime} 45^{\prime \prime} \mathrm{S}, 62^{\circ} 49^{\prime} 32^{\prime \prime} \mathrm{W}\right)$, RO, Brazil, was airdried in the shade, sifted $(5 \mathrm{~mm})$, and used to fill pots ( 5 $\mathrm{kg}$ capacity). The soil chemical and granulometric attributes (Raij et al., 1997) before the experiment was installed were: $\mathrm{pH}\left(\mathrm{CaCl}_{2} 0.01 \mathrm{~mol} \mathrm{~L}^{-1}\right)=4.9 ; \mathrm{OM}=3 \mathrm{~g}$ $\mathrm{dm}^{-3} ; \mathrm{P}($ resin $)=8 \mathrm{mg} \mathrm{dm}^{-3} ; \mathrm{K}=0.5 \mathrm{mmol}_{\mathrm{c}} \mathrm{dm}^{-3} ; \mathrm{Ca}=5$ $\mathrm{mmol}_{\mathrm{c}} \mathrm{dm}^{-3} ; \mathrm{Mg}=2 \mathrm{mmol}_{\mathrm{c}} \mathrm{dm}^{-3} ; \mathrm{H}+\mathrm{Al}=12 \mathrm{mmol}_{\mathrm{c}} \mathrm{dm}^{-3}$; $\mathrm{CEC} \stackrel{\mathrm{c}}{=} 19.5 \mathrm{mmol} \mathrm{dm}^{-3}$; bases saturation $=38 \%$; clay $=$ $170 \mathrm{~g} \mathrm{~kg}^{-1}$; silt $=30 \mathrm{~g} \mathrm{~kg}^{-1}$, and sand $=800 \mathrm{~g} \mathrm{~kg}^{-1}$.

The WTS was obtained from the Water Treatment Station of Araraquara, SP, which uses ferric chloride as coagulant and lime to controll $\mathrm{pH}$ in the reaction medium. The residue had the following chemical attributes: Organic-C $=10.5 \mathrm{~g} \mathrm{~kg}^{-1}, \mathrm{~N}=2.0 \mathrm{~g} \mathrm{~kg}^{-1}, \mathrm{P}=1.0 \mathrm{~g} \mathrm{~kg}^{-1}, \mathrm{~K}=$ $2.0 \mathrm{~g} \mathrm{~kg}^{-1}, \mathrm{Ca}=121 \mathrm{~g} \mathrm{~kg}^{-1}, \mathrm{Mg}=4.0 \mathrm{~g} \mathrm{~kg}^{-1}, \mathrm{~S}=4.0 \mathrm{~g} \mathrm{~kg}^{-1}$; $\mathrm{Cu}=149 \mathrm{mg} \mathrm{kg}^{-1}, \mathrm{Fe}=167,040 \mathrm{mg} \mathrm{kg} \mathrm{kg}^{-1}, \mathrm{Mn}=1,683$ $\mathrm{mg} \mathrm{kg}{ }^{-1}, \mathrm{Zn}=66 \mathrm{mg} \mathrm{kg}^{-1}, \mathrm{~B}=5,477 \mathrm{mg} \mathrm{kg}^{-1}, \mathrm{Cd}=6 \mathrm{mg}$ $\mathrm{kg}^{-1}, \mathrm{Cr}=86 \mathrm{mg} \mathrm{kg}^{-1}, \mathrm{Ni}=26 \mathrm{mg} \mathrm{kg}^{-1}$, and $\mathrm{Pb}=8 \mathrm{mg}$ $\mathrm{kg}^{-1}$ (dry basis). The granulometric attributes of the WTS were: clay $=425 \mathrm{~g} \mathrm{~kg}^{-1}$, silt $=315 \mathrm{~g} \mathrm{~kg}^{-1}$, and sand $=260$ $\mathrm{g} \mathrm{kg}^{-1}$ Organic $\mathrm{C}$ was determined by the wet digestion (Dabin, 1976). Nitrogen was determined in sulfuric digestion extract by steam distillation method (Sarruge \& Haag, 1974), while the other nutrients were determined in nitric-perchloric acid digestion extract (except B, obtained by dry digestion) by colorimetry $(\mathrm{P})$, flame photometry $(\mathrm{K})$, atomic absorption spectrophotometry $(\mathrm{Ca}$ and $\mathrm{Mg}$ ), and turbidimetry (S) according to Bataglia et al. (1983). Heavy metals were determined in the extract from digestion with $\mathrm{HNO}_{3}, \mathrm{HCl}$, and $\mathrm{H}_{2} \mathrm{O}_{2}$ (USEPA, 1986) by atomic absorption spectrophotometry.

A completely randomized experimental design was set up, in a $3 \times 5$ factorial arrangement, including three nitrogen doses supplied by WTS $\left(D_{100}=100, D_{200}=\right.$ 200 , and $\mathrm{D}_{300}=300 \mathrm{mg} \mathrm{N} \mathrm{kg}^{-1}$ soil, dry basis), five types of plants (brachiaria, Tanzania grass, velvet bean, sunn hemp, and false sicklepod) and two controls $\left(\mathrm{T}_{\mathrm{s}}=\right.$ soil without treatment and $\mathrm{T}_{\mathrm{m}}=$ soil + liming + mineral fertilization), with four replicates (68 plots).

For the WTS application, the pots $(10 \mathrm{~kg}$ capacity, containing $8 \mathrm{~kg}$ of degraded soil sieved to $5 \mathrm{~mm}$ ) received, each other day, $360 \mathrm{~g}$ wet sludge in the $\mathrm{D}_{100}$ and $\mathrm{D}_{200}$ treatments, and $640 \mathrm{~g}$ in the $\mathrm{D}_{300}$ treatment until the $\mathrm{N}$ dose established was reached. On the day following each application, the sludge was superficially incorporated. Considering a $6 \%$ solids content and a $2 \mathrm{~g} \mathrm{~kg}^{-1} \mathrm{~N}$ content in the sludge on average (dry basis), applications consisted of $5.7,11.4$, and $17.1 \mathrm{~kg}$ wet sludge per pot in the $\mathrm{D}_{100}$, $\mathrm{D}_{200}$, and $\mathrm{D}_{300}$ treatments, respectively. After the WTS application was finished, the soil contained in each pot was removed, air-dried in the shade, pounded to break up clods, passed through a sieve $(5 \mathrm{~mm})$, and homogenized. Later on, dolomitic lime was applied (67\% TNP) to all pots, except for the $\mathrm{T}_{\mathrm{s}}$ control, at a rate equivalent to $2 \mathrm{tha}^{-1}$; the soil was then homogenized and returned to its original pot, and distilled water was added to reach about $70 \%$ of the soil's retention capacity; this moisture content was maintained along the incubation period ( 25 days) by periodically replacing the water losses by evaporation. On the day plants were sown, the soil in the $\mathrm{T}_{\mathrm{m}}$ control pots received mineral fertilization consisting of $300 \mathrm{mg} \mathrm{N}$ (ammonium sulfate), $150 \mathrm{mg}$ P (triple superphosphate), and $100 \mathrm{mg} \mathrm{K}$ (potassium chloride) per $\mathrm{kg}$ soil. The pots also received 30 $\mathrm{mL}$ of a micronutrient solution $(0.96 \mathrm{~g}$ boric acid, $1.97 \mathrm{~g}$ copper sulfate pentahydrate, $3.08 \mathrm{~g}$ manganese sulfate tetrahydrate, $0.09 \mathrm{~g}$ sodium molybdate dihydrate, and 7.33 $\mathrm{g}$ zinc sulfate per liter) and $10 \mathrm{~mL}$ of a Fe-EDTA solution (Melo et al., 1998). In the WTS treatments, NPK was added to complete the content of these nutrients applied to the $\mathrm{T}_{\mathrm{m}}$ treatment. The $\mathrm{N}$ and $\mathrm{K}$ doses were applied half at sowing and half 30 days after sowing.

The pioneer species false sicklepod (Senna multijuga) was then planted in all treatments. The legumes Stizolobium aterrimum and Crotalaria juncea, and the grasses Brachiaria decumbens and Panicum maximum, were sowed 120 days later in the pots of the respective treatments. The following plant combinations were prepared for each treatment $\left(\mathrm{D}_{100}, \mathrm{D}_{200}\right.$, and $\left.\mathrm{D}_{300}\right)$ : false sicklepod + velvet bean, false sicklepod + sunn hemp, false sicklepod + brachiaria, false sicklepod + Tanzania grass, and false sicklepod alone. Sixty days after the legumes and grasses were sown, the plants were cut near the soil surface, the soil was removed from each pot, and roots were separated from the soil. The soil samples were air-dried in the shade, pounded to break up clods, homogenized, sieved $(2 \mathrm{~mm})$, and stored in polyethylene bags maintained in a dry chamber until analyser.

The soil samples were analyzed for soil fertility attributes (Raij et al., 1997), and for $\mathrm{Cu}, \mathrm{Fe}, \mathrm{Mn}$, and $\mathrm{Zn}$ extractable by DTPA solution at pH 7.0 (Lindsay \& Norwel, 1978) by atomic absorption spectrophotometry. 
Results were submitted to analysis of variance and means were compared by the Tukey's test $(P \leq 0.05)$, when the F test was significant $(P \leq 0.01)$, according to PimentelGomes (1990).

\section{RESULTS AND DISCUSSION}

In the $\mathrm{T}_{\mathrm{m}}$ control (soil + liming + chemical fertilization) increasing $\mathrm{pH}$, exchangeable bases $(\mathrm{K}, \mathrm{Ca}$, and $\mathrm{Mg}$ ) and $\mathrm{P}$ (resin) contents were recorded, and were higher in relation to the absolute control $\left(\mathrm{T}_{\mathrm{s}}\right)$, as a result of liming and fertilization. Organic matter content was not different in $\mathrm{T}_{\mathrm{m}}$ and $\mathrm{T}_{\mathrm{s}}$ (Table 1).

The application of WTS increased 1.8, 2.0, and $1.9 \mathrm{pH}$ units in the soil, respectively for $\mathrm{D}_{100}, \mathrm{D}_{200}$, and $\mathrm{D}_{300}$, in relation to $\mathrm{T}_{\mathrm{m}}$ (Tables 1 and 2). Even though liming was performed in all treatments, except $\mathrm{T}_{\mathrm{s}}$, these increases could be credited to the WTS, since $\mathrm{pH}$ was above the values obtained for $T_{m}$. The neutralizing action of the WTS occurs because lime $(\mathrm{CaO})$ is used as coadjuvant during the water treatment process.

Organic matter (OM) contents increased with WTS doses (Table 2). Although WTS is considered an inorganic residue (Elliott et al., 1990), the residue used in this experiment showed a total organic carbon content equal to $10.5 \mathrm{~g} \mathrm{~kg}^{-1}$ sludge (dry basis). This value, in association with the high doses used as a consequence of the $\mathrm{N}$ content in the sludge, helped to increase the amount of carbon in the degraded soil, consequently increasing OM content.

When compared with control, the WTS increased significantly P-resin content in the degraded soil; how- ever, no differences between doses were detected (Tables 1 and 2). If used at doses lower than those ones used in this experiment, WTS may cause soil P fixation, and a deficiency of this nutrient to plants, which leads to a necessity for mineral fertilizer supplementation (Bugbee \& Frink, 1985, cited by Cornwel, 1987). However, the Presin contents obtained in this work fall within very high $\left(\mathrm{D}_{100}\right.$ and $\left.\mathrm{D}_{200}\right)$ and high $\left(\mathrm{D}_{300}\right)$ ranges for forest species, and within medium ranges for annual species, according to the interpretation table of Raij et al. (1997).

$\mathrm{K}, \mathrm{Ca}$, and $\mathrm{Mg}$ contents increased with WTS application, and there were no differences in $\mathrm{Ca}$ and $\mathrm{K}$ contents between the $\mathrm{D}_{200}$ and $\mathrm{D}_{300}$ doses (Table 2). The contents obtained for these nutrients are classified as high according to IAC's interpretation table (Raij et al., 1997). However, the Ca contents were much higher than those considered appropriate by Malavolta et al. (1974). WTS is very rich in Ca because calcitic lime, which has higher Neutralizing Power (NP) than dolomitic lime is used in the water treatment, and that can cause problem related to $\mathrm{Mg}$ plant nutrition.

High $\mathrm{pH}$ values and high calcium concentrations are remarkable characteristics of high-lime soils. These conditions widely interfere with the ion adsorption and solubilization processes, which are responsible for the concentration of nutrients in the soil solution (Moreira et al., 2000). P precipitation, with the formation of calcium phosphate, is one of the reasons for the reduction of this element in the soil solution. Even though the soil presented high $\mathrm{pH}$ values, $\mathrm{P}$ was available at quantities considered adequate for plant nutrition (Table 2).

Table 1 - Fertility attributes in a soil degraded by tin mining submitted or not to liming and mineral fertilization and cultivation with velvet bean, sunn hemp, brachiaria, Tanzania grass, and with the pioneer species false sicklepod in the controls treatment.

\begin{tabular}{|c|c|c|c|c|c|c|c|c|c|}
\hline Control & $\begin{array}{c}\mathrm{pH} \\
\mathrm{CaCl}_{2}\end{array}$ & $\mathrm{OM}$ & $\mathrm{P}($ resin) & $\mathrm{Ca}$ & $\mathrm{Mg}$ & K & $\mathrm{H}+\mathrm{Al}$ & SB & CEC \\
\hline & & $\mathrm{g} \mathrm{dm}^{-3}$ & $\mathrm{mg} \mathrm{dm} \mathrm{m}^{-3}$ & ------ & 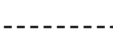 & $\cdots n$ & $m^{-3}-\cdots$ & $-\cdots$ & - \\
\hline $\mathrm{T}_{\mathrm{s}}{ }^{1}$ & $5.4 \mathrm{~b}$ & 3 a & $6 \mathrm{~b}$ & $5 \mathrm{~b}$ & $1.25 \mathrm{~b}$ & $2 b$ & $10 \mathrm{~b}$ & $8.4 \mathrm{a}$ & $18.7 b^{2}$ \\
\hline $\mathrm{T}_{\mathrm{m}}$ & $6.0 \mathrm{a}$ & $3 \mathrm{a}$ & $16 \mathrm{a}$ & $15 \mathrm{a}$ & $11.5 \mathrm{a}$ & $3 \mathrm{a}$ & $12 \mathrm{a}$ & $29.2 \mathrm{a}$ & $41.4 \mathrm{a}$ \\
\hline
\end{tabular}

${ }^{1} \mathrm{~T}_{\mathrm{s}}=$ degraded soil without the addition of fertilizers and corrective amendments. $\mathrm{T}_{\mathrm{m}}=$ degraded soil that received liming and chemical fertilizers. ${ }^{2}$ Means followed by the same letters in the column are not different by the Tukey's test $(P \leq 0.05)$.

Table 2 - Fertility attributes of a soil degraded by tin mining after the addition of WTS and cultivation with velvet bean, sunn hemp, brachiaria, Tanzania grass, and the pioneer species false sicklepod.

\begin{tabular}{|c|c|c|c|c|c|c|c|c|c|}
\hline Treatment & $\begin{array}{c}\mathrm{pH} \\
\mathrm{CaCl}_{2}\end{array}$ & $\mathrm{OM}$ & $\mathrm{P}($ resin) & $\mathrm{Ca}$ & $\mathrm{Mg}$ & K & $\mathrm{H}+\mathrm{Al}$ & SB & CEC \\
\hline & & $\mathrm{g} \mathrm{dm}^{-3}$ & $\mathrm{mg} \mathrm{dm} \mathrm{dm}^{-3}$ & $-\ldots-\ldots$ & $\cdots$ & ---1 & $m^{-3}-\cdots$ & $-\cdots-1-1$ & $-\ldots$ \\
\hline $\mathrm{D}_{100}^{1}$ & $7.8 \mathrm{~b}$ & $5 \mathrm{c}$ & 23 a & $267 \mathrm{~b}$ & $18 \mathrm{c}$ & $2 b$ & $6 \mathrm{a}$ & $287.6 \mathrm{~b}$ & $293 b^{2}$ \\
\hline $\mathrm{D}_{200}$ & $8.0 \mathrm{a}$ & $6 \mathrm{~b}$ & $21 \mathrm{a}$ & $331 \mathrm{a}$ & $37 \mathrm{~b}$ & $4 \mathrm{a}$ & $6 \mathrm{a}$ & $374.5 \mathrm{a}$ & $380 \mathrm{a}$ \\
\hline $\mathrm{D}_{300}$ & $7.9 \mathrm{ab}$ & $7 \mathrm{a}$ & 19 a & $334 \mathrm{a}$ & $43 \mathrm{a}$ & $4 \mathrm{a}$ & $6 \mathrm{a}$ & $381.7 \mathrm{a}$ & 388 a \\
\hline
\end{tabular}

${ }^{1} \mathrm{D}_{100}, \mathrm{D}_{200}$, and $\mathrm{D}_{300}=$ addition, respectively, of 100,200 , and $300 \mathrm{mg} \mathrm{WTS-N} \mathrm{kg}{ }^{-1}$ soil. ${ }^{2}$ Means followed by the same letters in the column are not different by the Tukey's test $(P \leq 0.05)$. 
When increasing $\mathrm{Ca}$ contents are not accompanied by increasing in $\mathrm{Mg}$ contents, the $\mathrm{Ca} / \mathrm{Mg}$ ratio may change, with detrimental effects to plant nutrition. At the $\mathrm{D}_{100}, \mathrm{D}_{200}$, and $\mathrm{D}_{300}$ doses, the $\mathrm{Ca}: \mathrm{Mg}$ ratio was 15:1, 9:1, and $8: 1$, respectively. These ratios are above the value that is considered adequate $(4: 1)$. However, according to Raij et. al. (1997), the Ca:Mg ratio is important when one of these nutrients is at low concentrations in the soil; otherwise, values varying from 1 to above 30 are not detrimental to plant growth.

The interaction between WTS doses $\times$ cultivated plants was only significant for $\mathrm{K}$ (Table 3 ). For $\mathrm{D}_{100}$ and $\mathrm{D}_{300}$, soil $\mathrm{K}$ content did not vary between treatments containing plants, but for $\mathrm{D}_{200}$ it was lower in treatments containing legumes. The legumes showed faster initial development than the grasses and the pioneer plant, uptaking more $\mathrm{K}$, with consequent decrease in their concentration in the soil. $\mathrm{K}$ does not take part in precipitation or adsorption reactions because of the effect of $\mathrm{Ca}$. However, the high ratios between $\mathrm{Ca}$ and $\mathrm{K}$ obtained in the $\mathrm{D}_{100}, \mathrm{D}_{200}$, and $\mathrm{D}_{300}$ treatments, respectively $134: 1$, $83: 1$, and $84: 1$, may result in $\mathrm{K}$ deficiency by inhibition of its absorption (Malavolta et al., 1997).

WTS increased cation exchange capacity (CEC) and sum of bases (SB) and decreased potential acidity $(\mathrm{H}+\mathrm{Al})$ (Table 2). According to Raij (1991), increased CEC might be related to the presence of 1:1 clay minerals, of $\mathrm{Fe}, \mathrm{Al}$, and $\mathrm{Mn}$ oxides, and of organic matter itself, whose negative charges depend on $\mathrm{pH}$. The WTS used in this experiment had high amounts of clay in its composition, as well as high amounts of other elements. Soils of the hydrographic watershed from where water is collected for treatment in Araraquara, SP, are derived from basaltic rocks. It is thus fair to infer that part of this clay has negative charges that may improve the physical properties of the degraded soil. However, the CEC value was obtained by the sum of free cations in solution $\left(\mathrm{K}^{+}, \mathrm{Ca}^{2+}\right.$, and $\left.\mathrm{Mg}^{2+}\right)$; since there was an

Table $3-\mathrm{K}$ in a soil degraded by tin mining submitted to WTS doses and cultivation with legumes, grasses and a native specie.

\begin{tabular}{lccccc}
\hline \multirow{2}{*}{ Treatment } & \multicolumn{5}{c}{$\mathrm{K}$} \\
\cline { 2 - 6 } & $\mathrm{P} 1$ & $\mathrm{P} 2$ & $\mathrm{P} 3$ & $\mathrm{P} 4$ & $\mathrm{P}^{1}$ \\
\hline & $-1 \mathrm{Ab}$ & $2 \mathrm{Ab}$ & $3 \mathrm{Ac}$ & $3 \mathrm{Ab}$ & $2 \mathrm{Ab}^{3}$ \\
$\mathrm{D}_{100}{ }^{2}$ & $2 \mathrm{Bb}$ & $3 \mathrm{Bb}$ & $5 \mathrm{Aa}$ & $5 \mathrm{Aa}$ & $4 \mathrm{Aba}$ \\
$\mathrm{D}_{200}$ & $4 \mathrm{Aa}$ & $5 \mathrm{Aa}$ & $4 \mathrm{Ab}$ & $4 \mathrm{Aa}$ & $4 \mathrm{Aa}$ \\
$\mathrm{D}_{300}$ & 4
\end{tabular}

${ }^{1} \mathrm{P} 1=$ velvet bean + false sicklepod, $\mathrm{P} 2=$ sunn hemp + false sicklepod, P3 = brachiaria + false sicklepod, P4 $=$ Tanzania grass + false sicklepod, P5 - false sicklepod alone. ${ }^{2} \mathrm{D}_{100}, \mathrm{D}_{200}$, and $\mathrm{D}_{300}=$ addition, respectively, of 100,200 , and $300 \mathrm{mg}$ WTS- $\mathrm{N} \mathrm{kg}^{-1}$ soil. ${ }^{3}$ Means followed by the same upper case letter in the row, and lower case letter in the column, are not different by the Tukey's test $(P \leq 0.05)$. excess of free cations, mainly $\mathrm{Ca}^{2+}$, because of the type of the sludge and the doses used, it can be assumed that it was overestimated (Raij et al.; 1987, Raij, 1991).

The micronutrient contents in the control and in the treatments receiving WTS are presented in Tables 4 and 5. According to limits listed in Raij et al. (1997), the contents obtained for $\mathrm{Cu}, \mathrm{Fe}$, and $\mathrm{Zn}$ are considered high, while those obtained for $\mathrm{Mn}$, as well as those obtained for $\mathrm{B}$ at the $\mathrm{D}_{100}$ dose, are considered medium. However, for the $\mathrm{D}_{200}$ and $\mathrm{D}_{300}$ doses the $\mathrm{B}$ contents obtained were low, and may limit plant growth (Table 5), including the values obtained in the controls.

The effect of the interaction between doses $\times$ cultivated plants was significant for $\mathrm{Cu}$ and $\mathrm{Fe}$ (Tables 6 and 7). At the $\mathrm{D}_{200}$ dose, the contents of these elements decreased where the pioneer species false sicklepod was grown. However, plants showed little development in all treatments, eliminating the hypothesis of greater $\mathrm{Cu}$ and Fe absorption to explain those reductions.

Fe was found at high amounts in DTPA-extractable form, which can be explained by the presence of ferric chloride in the residue which is originated from the water treatment process. The contents obtained were above those considered adequate by Raij et al. (1997). Among the possible implications for plant nutrition, the excess available $\mathrm{Fe}$ in the soil may inhibit $\mathrm{Cu}$ and $\mathrm{Mn}$

Table 4 - Micronutrients in a soil degraded by tin mining submitted or not to liming and mineral fertilization and cultivation with velvet bean, sunn hemp, brachiaria, Tanzania grass, and with the pioneer species false sicklepod in the controls treatment.

\begin{tabular}{lccccc}
\hline Treatment & $\mathrm{B}$ & $\mathrm{Cu}$ & $\mathrm{Fe}$ & $\mathrm{Mn}$ & $\mathrm{Zn}$ \\
\hline $\mathrm{T}_{\mathrm{s}}{ }^{1}$ & $0.04 \mathrm{~b}$ & $0.1 \mathrm{~b}$ & $2 \mathrm{a}$ & $0.7 \mathrm{a}$ & $0.1 \mathrm{~b}^{2}$ \\
$\mathrm{~T}_{\mathrm{m}}$ & $0.32 \mathrm{a}$ & $0.7 \mathrm{a}$ & $3 \mathrm{a}$ & $0.9 \mathrm{a}$ & $2.7 \mathrm{a}$ \\
\hline
\end{tabular}

${ }^{1} \mathrm{~T}_{\mathrm{s}}=$ degraded soil without the addition of fertilizers and corrective amendments. $\mathrm{T}_{\mathrm{m}}=$ degraded soil that received liming and chemical fertilizers. ${ }^{2}$ Means followed by the same letters in the column are not different by the Tukey's test $(P \leq 0.05)$.

Table 5 - Micronutrients in a soil degraded by tin mining after the addition of WTS and cultivation with velvet bean, sunn hemp, brachiaria, Tanzania grass, and the pioneer species false sicklepod.

\begin{tabular}{|c|c|c|c|c|c|}
\hline Treatment & B & $\mathrm{Cu}$ & $\mathrm{Fe}$ & $\mathrm{Mn}$ & $\mathrm{Zn}$ \\
\hline & \multicolumn{5}{|c|}{ - } \\
\hline $\mathrm{D}_{100}^{1}$ & $0.22 \mathrm{a}$ & $1.8 \mathrm{~b}$ & $50 \mathrm{c}$ & $3.2 \mathrm{~b}$ & $4 \mathrm{a}^{2}$ \\
\hline $\mathrm{D}_{200}$ & $0.19 \mathrm{~b}$ & $2.4 \mathrm{a}$ & $75 \mathrm{~b}$ & $4.4 \mathrm{a}$ & $2.8 \mathrm{~b}$ \\
\hline $\mathrm{D}_{300}$ & $0.13 \mathrm{c}$ & $2.6 \mathrm{a}$ & $84 \mathrm{a}$ & $4.5 \mathrm{a}$ & $2.5 \mathrm{~b}$ \\
\hline
\end{tabular}

${ }^{1} \mathrm{D}_{100}, \mathrm{D}_{200}$, and $\mathrm{D}_{300}=$ addition, respectively, of 100,200 , and 300 mg WTS-N kg-1 soil. ${ }^{2}$ Means followed by the same letters in the column are not different by the Tukey's test $(P \leq 0.05)$. 
Table 6 - Copper in a soil degraded by tin mining submitted to WTS doses and cultivation with legumes, grasses and a pioneer specie.

\begin{tabular}{lccccc}
\hline \multirow{2}{*}{ Treatment } & \multicolumn{4}{c}{$\mathrm{Cu}$ content } \\
\cline { 2 - 5 } & $\mathrm{P} 1$ & $\mathrm{P} 2$ & $\mathrm{P} 3$ & $\mathrm{P} 4$ & $\mathrm{P}{ }^{1}$ \\
\hline $\mathrm{D}_{100}{ }^{2}$ & $1.5 \mathrm{Ab}$ & $2.0 \mathrm{Aa}$ & $2.0 \mathrm{Ab}$ & $1.7 \mathrm{Ab}$ & $1.6 \mathrm{Ab}$ \\
$\mathrm{D}_{200}$ & $3.0 \mathrm{Aa}$ & $2.2 \mathrm{ABa}$ & $2.8 \mathrm{Aa}$ & $2.7 \mathrm{Aa}$ & $1.7 \mathrm{Bb}$ \\
$\mathrm{D}_{300}$ & $2.5 \mathrm{Aa}$ & $2.6 \mathrm{Aa}$ & $2.7 \mathrm{Aa}$ & $2.5 \mathrm{Aa}$ & $2.8 \mathrm{Aa}$ \\
\hline
\end{tabular}

${ }^{1} \mathrm{P} 1=$ velvet bean + false sicklepod, $\mathrm{P} 2=$ sunn hemp + false sicklepod, $\mathrm{P} 3=$ brachiaria + false sicklepod, $\mathrm{P} 4=$ Tanzania grass + false sicklepod, P5 - false sicklepod alone. ${ }^{2} \mathrm{D}_{100}, \mathrm{D}_{200}$, and $\mathrm{D}_{300}=$ addition, respectively, of 100,200 , and $300 \mathrm{mg}$ WTS-N kg-1 soil. ${ }^{3} \mathrm{Means}$ followed by the same upper case letter in the row, and lower case letter in the column, are not different by the Tukey's test $(P \leq 0.05)$.

Table 7 - Fe in a soil degraded by tin mining submitted to WTS doses and cultivation with legumes, grasses and a pioneer specie.

\begin{tabular}{|c|c|c|c|c|c|}
\hline \multirow{2}{*}{ Treatment } & \multicolumn{5}{|c|}{$\mathrm{Fe}$ content } \\
\hline & $\mathrm{P} 1$ & $\mathrm{P} 2$ & P3 & $\mathrm{P} 4$ & $\mathrm{P} 5^{1}$ \\
\hline & $\ldots$ & $\ldots$ & $\mathrm{mg} \mathrm{dm} \mathrm{m}^{-3}$ & $\ldots$ & - \\
\hline $\mathrm{D}_{100}{ }^{2}$ & $53 \mathrm{Ab}$ & $54 \mathrm{Ab}$ & $52 \mathrm{Ab}$ & $45 \mathrm{Ab}$ & $47 \mathrm{Ab}^{3}$ \\
\hline $\mathrm{D}_{200}$ & $80 \mathrm{Aa}$ & $74 \mathrm{Aa}$ & $83 \mathrm{Aa}$ & $80 \mathrm{Aa}$ & $58 \mathrm{Bb}$ \\
\hline $\mathrm{D}_{300}$ & 89 Аа & $81 \mathrm{Aa}$ & 84 Aa & $84 \mathrm{Aa}$ & $83 \mathrm{Aa}$ \\
\hline
\end{tabular}

${ }^{1} \mathrm{P} 1=$ velvet bean + false sicklepod, $\mathrm{P} 2=$ sunn hemp + false sicklepod, $\mathrm{P} 3=$ brachiaria + false sicklepod, $\mathrm{P} 4=$ Tanzania grass + false sicklepod, P5 - false sicklepod alone. ${ }^{2} \mathrm{D}_{100}, \mathrm{D}_{200}$, and $\mathrm{D}_{300}=$ addition, respectively, of 100,200 , and $300 \mathrm{mg}$ WTS-N kg-1 soil. ${ }^{3} \mathrm{Means}$ followed by the same upper case letter in the row, and lower case letter in the column, are not different by the Tukey's test $(P \leq 0.05)$.

absorption. Such inhibition effect may also be verified for the $\mathrm{Ca} / \mathrm{Cu}$ ratio, that is, excess $\mathrm{Ca}$ in the soil may inhibit $\mathrm{Cu}$ absorption by the plants (Malavolta et al., 1997).

\section{REFERENCES}

BARTH, R.C. Reclamation technology for tiling impoundments - part 2 revegetation. Mineral \& Energy, v.19, p.1-25, 1986.

BATAGLIA, O.C.; TEIXEIRA, J.F.; FURLANI, P.R.; FURLANI, M.C.; GALLO, J.R. Métodos de análise química de planta. Campinas: Instituto Agronômico, 1983. 31p. (Circular, 87).

COMPANHIA DE SANEAMENTO BÁSICO DO ESTADO DE SÃO PAULO - SABESP. Recuperação de águas de lavagens, tratamento e disposição de resíduos sólidos de ETAs da RMSP. Revista DAE, v.47, p.216-219, 1987.

COPPIN, N.J.; BRADSHAW, A.D. Quarry reclamation: the establishment of vegetation in quarries and nonmetal mines. London: Mining Journal Books, 1982. 112p.

CORNWELL, D.A. Handbook of practice: water treatment plant waste management. Denver: AWWA, 1987. 459p.

DABIN, B. Curso sobre matéria orgânica do solo. Parte 1. Análise dos compostos húmicos do solo. Piracicaba: CENA, 1976. 115p.

ELLIOTT, H.A.; DEMPSEY, B.A.; HAMILTON, D.W.; DEWOLFE, J.R. Land application of water treatment sludges: impacts and management. Washington: AWWA Research Foundation, American Water Works Association, 1990. 100p.

FONSECA, D.M. da Níveis críticos de fósforo em amostras de solos para o estabelecimento de Andropogon gayanus, Brachiaria decumbens e Hyparrhenia rufa. Viçosa: UFV, 1987. 146p. (Dissertação - Mestrado).

GRIFFITH, J.J.; WILLIAMS, D.D.; FRANCO, R.M.; BRETAS, F.S. Funções múltiplas das florestas. Conservação e recuperação do meio ambiente. In: CONGRESSO FLORESTAL BRASILEIRO, 6., Campos de Jordão, 1990. Trabalhos voluntários; resumos. Campos do Jordão: SBS; SBEF, 1990. p.69-77.

LINDSAY, W.L.; NORWEL, W.A. Development of a DTPA soil test for zinc, iron, manganese and copper. Soil Science Society of America Journal, v.42, p.421-428, 1978.
MALAVOLTA, E.; VITTI, G.C.; OLIVEIRA, S.A. Avaliação do estado nutricional das plantas: princípios e aplicações. Piracicaba: POTAFOS, 1997. 319p.

MALAVOLTA, E.; HAAG, H.P.; MELLO, F.A.; BRASIL SOBRINHO, M.C.O. Nutrição mineral e adubação de plantas cultivadas. São Paulo: Pioneira, 1974. 727p.

MELO, W.J.; MELO, G.M.P.; BERTIPAGLIA, L.M.A.; MELO, V.P. Experimentação sob condições controladas. Jaboticabal: FUNEP, 1998. 86p

MOREIRA, A.; FRANCHINI, J.C.; MORAES, L.A.C.; MALAVOLTA, E. Disponibilidade de nutrientes em vertissolo calcário. Pesquisa Agropecuária Brasileira, v.35, p.2107-2113, 2000.

PIMENTEL-GOMES, F. Curso de estatística experimental. Piracicaba: Nobel, 1990. 468p.

RAIJ, B. van. Fertilidade do solo e adubação. Piracicaba: Ceres, 1991. $343 p$.

RAIJ, B. van; QUAGGIO, J.A.; CANTARELLA, H.; FERREIRA, M.E.; LOPES, A.S.; BATAGLIA, O.C. Análise química do solo para fins de fertilidade. Campinas: Fundação Cargil, 1987. 170p.

RAIJ, B. van; CANTARELLA, H.; QUAGGIO, J.A.; FURLANI, A.M.C. Recomendação de adubação e calagem para o Estado de São Paulo. 2.ed. Campinas: Instituto Agronômico; Fundação IAC, 1997. 285p. (Boletim Técnico, 100).

ROCHA, G.L. Perspectivas e problemas de adubação de pastagens no Brasil. In: MATTOS, H.B.; ERNER, J.C.; YAMADA, T.; MALAVOLTA, E. (Ed.) Calagem e adubação de pastagens. Piracicaba: Associação Brasileira para Pesquisa da Potassa e do Fosfato, 1986. p.1-29.

SARRUGE, J.R.; HAAG, H.P. Análises químicas em plantas. Piracicaba: ESALQ/USP, 1974. 56p.

SILVA, K.E.; VALE, A.B.; BARROS, N.F.; GARCIA, R. Utilização de rejeito de mineração de ferro em combinação com solo para revegetação. Revista Árvore, v.19, p.405-14, 1995.

USEPA. Test method for evaluating solid waste. Report Number SW846. Washington: EPA, 1986. (Code of Federal Regulations 40 CFR Part 503)

Received August 16, 2004

Accepted October 06, 2005 